sultat dieser Rechnung folgende verbesserten Eleniente der Bahn erhalten :

Zeit der $\odot$ Nähe 1825 Dec. 10,464215 Prager M.Z.

Neigung der Bahn $=33^{\circ} 31^{\prime} 58.5$

Länge des $\delta 8=2154344,2$

Länge der $\odot$ Nähe $=318^{\circ} 55^{\prime} 40^{\prime \prime}, 6$

Log. des kl. Abstandes $=0,0942050$

Bewegung rückläufig.
Heliocent. Courdinaten auf den Aequator.

$$
\begin{aligned}
& x=-\overline{0,0703443} \cdot \frac{\operatorname{Sin}\left(315^{\circ} 51^{\prime} 12^{\prime \prime}, 0-v\right)}{\operatorname{Cos}^{2} \frac{1}{2} v} \\
& y=+\overline{9,9196353} \cdot \frac{\operatorname{Sin}\left(203 \frac{3620,4-v)}{\operatorname{Cos}^{2} \frac{1}{2} v}\right.}{\operatorname{Cos}^{2} \frac{x}{2} v}
\end{aligned}
$$

*) Die überstrichenen Zahleñ sind schon Logarithmen.

J. Morstadt.

Auszug aus einem Schreiben des Herrn C. $T$. Schmidel an den Herausgeber. Zehmen 1826. Febr. 1.

Beigeschlossen bin ich so frei Ilhnen die Zusammenstellung aller frühern Beobachtungen zur Bestimmung der Länge der Leipziger Sternwarte zu überreichen. Die Veranlassung zu derselben war eine kleine Triangulation, vermittelst welcher ich meinen Beobachlungsort mit Leipzig verbunden habe, und deren Resultat die Breite von Zehmen auf $51^{\circ} 13^{\prime} 51^{\prime \prime}, 4$ und die Länge auf $7^{\prime \prime}, 5$ in Zt. östl. von Leipzig setzt.

Die Cometen habe ich aus Mangel eines Kreismicrometers nicht beobachten können, nur den Bielaschen konnte ich zweimal im Passage-Instrument eehn, doch erlauble sein schwaches Licht nur abwechseInde Erleuchtung der Fäden.

Octbr. 6.
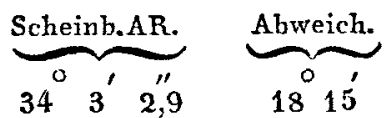

8.

$\begin{array}{rrr}34 & 3 & 2,9 \\ 29 & 37 & 30,0\end{array}$

-

Die Zeit berult auf Besselsche Sterne nach thren Hülfstafeln.

Von Sternbedeckungen kann ich Ibnen wegen der ausnehmend schlechten Wilterung des Herbstes und der ersten Hälfte des Winters nur eine einzige mittheilen, Der Eintritt ist mit grolser Schärfe beobachtet worden, der Austrilt jedoch bis auf wahrscheinlich $2^{\prime \prime}$ zu spät.
Oct. 17. $2 \xi$ Sagitt. E. $19^{h} 17^{\prime} 16,15$ Sternz. am dunkeln Mondrande.

A. 202412,05 Sternzt. am hellen Mondrande.

Scheinb. Culm. des $1^{\text {sten }}$ Mondrandes $18^{\text {h }} 44^{\prime} 30^{\prime \prime}, 8$ Sternzeit. Die Zeit beruht auf die Durchgänge von $\propto$ Can. min., $\alpha$ u. $\beta$ Aquilae und 1 u. $2 \alpha$ Capricorni. Der Gang meiner Uhr ist sehr gut und im Durchschnitt $1^{\prime \prime}, 5$ täglich vor Sternzeit voreilend. Bei jeder Beobachtung nebme ich vorher und nachher einige Durchgänge, um eine ganz zuverlässige Zeilbestimmung zu haben und zur Prüfung der Lage des $\mathbf{P}$. Instr, obere und untere Culminationen.

\section{Chr. Theod. Schmidel.}

Nachschr. Am 12ten Juli v. J. habe ich in Gesellschaft des Hrn. Prof. Möbius, des Hrn. Major Arter und des Hrn. Mag. Drobisch die Abweichung der Magnetnadel bestimmt. Das Instrument stand zwischen der Sternwarte und dem Mittagszeichen. Die Winkel wurden mit einem Theodolith von Ramsden gemessen. Die $\mathrm{Mbw}$. betrug $17^{\circ} 45^{\prime}$ wesll. Seit 1749 war keine Bestimmung derselben gemacht worden.

\title{
Ueber die Länge der Leipziger Sternwarte.
}

Der Zeitpunkt, wo nach einer zwanzigjährigen Ruhe (welche durch die sich immer verzögernde Aufstellung der Brühlschen Instrumente herbeigeführt wurde) die Leipziger Sternwarte wieder in Thäligkeit getreten ist, schrint mir zu einer Zusammenstellung der früheren Bemühungen der Herren v. Zach, Triesnecker, Lalande und Wurm die Länge derselben zu bestimmen geeignet zu seyn, indem sie einestheils Gelegenheit giebt, die nenern Resultate an die ällern zu knüpfen, anderntheils die seit vielen Jahren in der Conn. des tems wahrscheinlich fehlerhaft angegebenen Länge zu berichligen erlaubt. Der erste Versuch über diesen Gegensland rïhrt von Herrn $\nu_{\text {. Zach, welcher }}$ in Jahre 1788 *) mittelst-seiner trefflichen Zeitmesser, die Seeuhr von Mudge und der Chronometer von Emery,

*) Bode Astr. Jahrbuch für 1791. S. 160. 
den Zeitunterschied zwischen Leipzig (Paulinum) *) und Seeberg $=6^{\prime} 33^{\prime \prime}$ in Zeit fand, woraus sich für Leipzig, weil Seeberg $33^{\prime} 35^{\prime \prime}$ in Zeit von Paris, eine Länge von $\left.40^{\prime} 8^{\prime \prime} *^{*}\right)$ fïr den Beobachtungsort, oder von $40^{\prime} 7^{\prime \prime}$ in $\mathrm{Zt}$. für die Sternwarte ergiebl.
Die weitern Bestimmungen beruhn allein auf Sumnen. fiusternissen und Sternbedeckungen. Der bequenern Uebersicht wegen folgen sie tabellarisch:

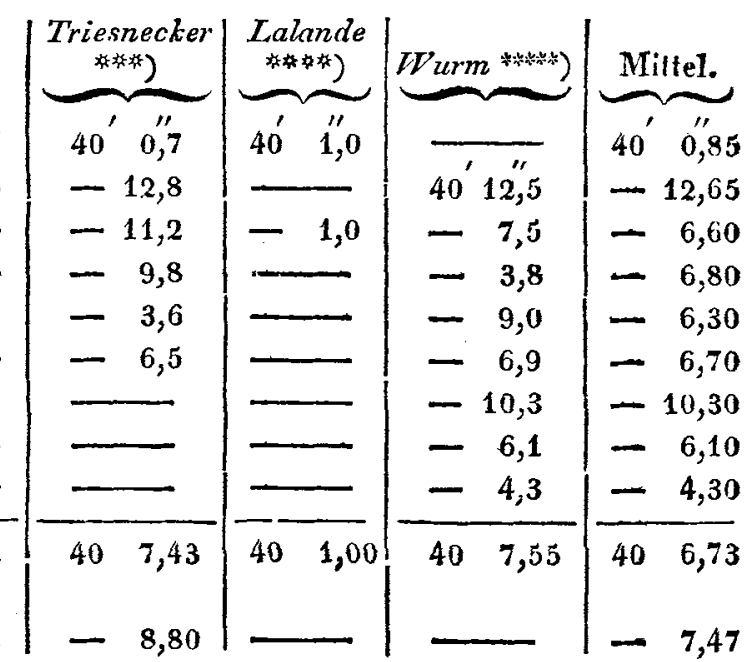

Das nahe Zusammentreffen des Mittels aus sämmtlichen Berechnungen mit der durch die Zeitmesser erhaltenen Länge, die Nähe Seebergs bei Uebertragung der Zeit und der vorzügliche Gang der englischen Uhren dürfte wohl keinen Zweifel übrig lassen, bis auf weitere Bestimmungen die Länge der Leeipziger Sternwarle zu $40^{\prime} 7^{\prime \prime}$ bis $40^{\prime} 7^{\prime \prime}, 25$ (statt der in der Conn. des tems von $40^{\prime} 6^{\prime \prime}$ ) anzunehmen. C. T. Schmiclel.

*) Dieses Gebäude liegt nach einem Grundrifs der Stad‡ $1^{\prime \prime}, 0$ in Zeit östlicher und 12" in B. nördlicher, als die Sternwarte.

**) Herr v. Zuch findet zwar a. a. O. die Länge $=40^{\prime} 13^{\prime \prime}$, dies beruht aber auf die damals um $5^{\prime \prime}$ zu grofs angenommene Länge von Seeberg.

***) A. G. E. B, I. S. 419. M. C. B.T. S.598. A. G. E. B.4. S. 395. M. C. B. 2. S. 483.485.

****) A. G. E. B. I. S. 675 . B. 2. S. 550 .

*****) A. G. E. B. 4. S. 112 u. M. C. B. 2. S. 270. A. G. E. B. 3. S. 568 u. M. C. B. 2. S. 270. A. G. E. B. 3. S. 569 u. M. G. B. 2. S. 270 . M. C. B. 8. S.123. B.7. S.492. B.8. S. 124. B. 12. S.353. B. 23. S. 534.

\section{Auszug aus einem Schreiben des Herrn F. Baily an den Herausgeber.} London 1826. Jan. 19.

I will relate to you a curious circumstance, which occurred in the course of the last summer, and which perhaps you will think ought to be made public, in order to show how the good intentions of parties may be occasionally frustrated. It appears that M. Struve, about 5 years ago, forwarded several copies of the first volume of his Observations at Dorpat, to the Royal Society. This parcel did not reach the Royal Society in due course; but lately came into my possession, in the following singular manner. It appears that M. Bowditch the celebrated American astronomer, was one day passing along the streets of Boston (in America) and was attracted by one of those volumes, which was lying in the window of a bookseller's shop. On enquiring he found that the bookseller had pur. chased them, with sone other hooks, either at Hamburg or at some of the contiguous sea ports: and on further inspection he found the remaining copies still untouched, in the original parcel. On opening the parcel the letter of M. Struve to the Secretary of the Royal Society was discovered: which clearly explained the original destination of the works. - Mr. Bowditch immediaiely redeemed the parcel, and forwarded it to me: and $[$ have since delivered it to the Royal Society, after a long and circuitous royage of 5 years from Dorpat to Buston, and from Boston to London. 